\title{
Nuclear Energy for Everyone, Nuclear Weapons for No-One
}

\author{
Makarim Wibisono
}

Universitas Airlangga

\begin{abstract}
The article explores the complicated nature of non-proliferation of nuclear weapons even though from the military, ethical and legal perspective, the destructiveness, immorality and illegality of the current situation cannot be perpetuated. Some of the nuclear-weapon states, however, have consistently refused to agree to any approach under multilateral auspices for the abolition of nuclear weapons. Rather, attention has been deflected to the horizontal proliferation of nuclear weapons, while the equally urgent task of complying with the legal obligation of implementing Article VI of the Non-Proliferation Treaty (NPT) concerning nuclear disarmament has been marginalized. I argue, no form of warfare would confront humanity with dangers even remotely comparable with the danger of nuclear warfare. Such disaster would affect the world economy and other vital aspects of the global infrastructure. The sudden collapse of many of the world's leading trading nations as well as the mechanisms for international transactions would lead to profound disorganization and leave other nation. In addition to the human cost, the ecology of the world would be severely affected and the infrastructure of civilization would be shattered.
\end{abstract}

Keywords: nuclear weapons, danger of proliferation, instability, multilateral auspices

Artikel ini membahas tentang non-proliferasi senjata nuklir yang terbukti rumit walaupun dari sudut militer, etika dan hukum, hal ini tidak sejalan dengan moralitas dan legalitas. Sekalipun demikian, beberapa negara pemilik senjata nuklir secara konsisten menolak untuk menyetujui pendekatan apapun yang dilakukan di bawah pengawasan multilateral untuk penghapusan senjata nuklir. Sebaliknya, perhatian telah dibelokkan ke proliferasi horizontal senjata nuklir, sementara kepatuhan hukum untuk pelaksanaan Pasal VI Perjanjian Non-Proliferasi (NPT) mengenai perlucutan senjata nuklir telah terpinggirkan. Penulis berpendapat, tidak ada bentuk peperangan yang paling berbahaya selain bahaya perang nuklir yang akan berdampak pada perekonomian dunia dan aspek penting lainnya dari infrastruktur global. Singkatnya, di samping biaya manusia, ekologi dunia akan menjadi parah dan infrastruktur peradaban akan hancur.

Kata kunci: senjata nuklir, bahaya proliferasi, ketidakstabilan, pengawasan multilateral 
Nuclear weapons made their fateful appearance on the international scene in the year that the United Nations was born. Although the Charter contains no reference to such weapons, they have been one of the major items on the United Nations agenda throughout its existence. The very first General Assembly resolution called for 'the elimination from national armaments of atomic weapons and of all major weapons adaptable to mass destruction'. However, the path subsequently taken led instead to relentless nuclear arms race that lasted for almost five decades. More than two thousand nuclear-weapons tests were conducted for qualitative improvement and greater sophistication. There are now thousands of nuclear weapons in the arsenals of the nuclear-weapon states.These developments have dangerous ramifications for the security, and even the survival, of humanity and have led to demands by an overwhelming majority of UN members for the elimination of nuclear weapons. Moreover, given the indiscriminate and destructive nature of these weapons, questions of purpose, deployment and national control have begun to loom large on the policy agendas of nearly every Government.

The threat posed by nuclear weapons has been universally recognized since their first use in 1945. In subsequent years, the avoidance of nuclear catastrophe has been generally attributed to the three C's command, control and communications - although no reliable system against accidents caused by technical failures or human fallibilities exists. Rather, as the arms control expert, Ambassador Richard Butler of Australia has written, it has been by good fortune that we have not experienced a nuclear disaster. It is the destructive potential of nuclear weapons which constitutes the moral imperative against them (Butler 1996). Such risks can only be reduced but not totally eliminated. In the nuclear age, the need for techniques to control force has not gone unrecognized. The search for such techniques, however, has had little success. 'Until a time arrives when all nuclear weapons are banned from the face of the Earth', Paul Bracken had remarked, the prudent path to security and survival lies through understanding how to manage and govern these forces'. History demonstrates that weapons once invented by man will be used: indeed, nuclear weapons have already been used in our lifetime. The horrendous toll of their use either as a deliberate political choice (according to unclassified information, such use was contemplated in the early 1950 os at the height of the Korean War, during the dispute over the Quemoy and Matsu Islands and perhaps in other instances) or by accident could lead to the loss of an indeterminate number of human lives and material devastation. All nations would experience grave physical consequence. Radioactive fallout could take a toll of millions world-wide, in present and future generations. 
The advisory opinion of the International Court of Justice on the legality of the threat or use of nuclear weapons issued in July 1996 has established that the unique characteristics of nuclear weapons and, in particular, their capacity to cause indescribable human suffering and inflict damage for generation to come render them potentially catastrophic. According to the Court, 'the destructive power of nuclear weapons cannot be contained in either space or time. They have the potential to destroy all civilization and the entire ecosystem of the planet.' Furthermore, the Court stated that the threat or use of nuclear weapons would generally be contrary to the rules of international law applicable in armed conflicts and, in particular, the principles and rules of international humanitarian law. It is especially significant that the Court concluded that there exists an obligation for all states to pursue in 'good faith' and bring to a conclusion negotiations leading to nuclear disarmament in all its aspects under strict and effective international control.

\section{The Obsolescence of Nuclear Weapons}

The declining military utility of nuclear weapons following the dissolution of the Warsaw Pact and the end of the military division of Europe has been obvious, and acknowledge even by some decisionmakers in the nuclear-weapon states. Prior to that, in a prophetic vein, some had foreseen such a development. In 1981 Admiral Noel Gaylor, former Commander-in-Chief of US Forces in the Pacific, observed before a Congressional Committee that 'there is no sensible military use of any of our nuclear forces. The only reasonable use is to deter our opponent from using his nuclear forces'. Former German Chancellor Helmut Schmidt, participating in a debate on nuclear issues in 1987 stated that 'flexible response is nonsense... The Western idea... that we should be willing to use nuclear weapons first, in order to make up for our so called conventional deficiency, has never convinced me'. And in December 1996 US General Lee Butler and over 6o Generals and Admirals from 21 countries, some of whom commanded nuclear forces, released a statement that 'the continuing existence of nuclear weapons in the armories of nuclear powers and the ever present threat of acquisition of these weapons by others, constitutes a peril to global peace and security and to the safety and survival of the people we are dedicated to protect'. They noted that 'in the post-Cold War security environment, the most commonly postulated nuclear threats are not susceptible to deterrence or are simply not credible'. The statement concluded that the threat will not finally recede' ...unless nuclear weapons are eliminated'(Christian Science Monitor1996). An impressive collection of similar quotes can be seen in pages 32 and 33 of the Report of the Canberra Commission on 
the Elimination of Nuclear Weapons issued in 1996 (Department of Foreign Affairs and Trade 1996).

It is sometimes contended that the threat or use of nuclear weapons, or a veiled or unstated threat to that effect, played a positive role during the Gulf War. But former US Secretary of State, James Baker, has pointed in his memoirs to the prior decision taken by the Coalition Forces 'not to retaliate with chemical or nuclear response even if attacked with chemical munitions' (Baker III andDe Frank 1995). The reasons for this decision are the same that were identified by the Canberra Commission: '... the consequences of nuclear retaliation ... might have been even more far-reaching than the threat it was seeking to deter' and, in particular, 'the use of threat it was weapons in response to use or threat of use of other weapons of mass destruction would cross an important psychological as well as military threshold, making the management of future conflicts even more uncertain'. Measures aimed at technological revolution have reduced the importance of nuclear weapons. Rapidly advancing information technologies, combined with stealthy weapons systems and precision-guided 'smart' munitions are revolutionizing nonnuclear strategic strike operations in ways that the have eliminated the need for reliance on nuclear weapons. Nuclear-weapon states must realize that alternatives to such weapons are becoming available in increasing numbers.

The possible remaining role for nuclear weapons is the deterrence of their use by other nuclear-weapon states. Initially, they attempted to rationalize the possession of nuclear weapons because of the Cold War. Now that the Cold War is over, they speak of unforeseen threats. They say they need them 'just in case'. But why are their national security needs more important than others? In reality, nuclear weapons have proven to be ineffective as a deterrent. It is difficult to prove that nuclear weapons kept the peace in Europe during the Cold War. It will never be proven that the threat or use of nuclear weapons compelled the adversaries to change or abandon their policies. It could be empirically proven that in confrontations between nuclear and non-nuclear states, nuclear weapons were not an effective and credible deterrent. Hiroshima and Nagasaki demonstrated the high risks involved in using nuclear weapons and this was the primary reason for their non-use in Vietnam. They played no role in the Gulf War. And in some of the recent violent ethnic conflicts, no country contemplated the use of nuclear weapons. It is therefore undeniable that deterrence has lost whatever justification claimed for it during and especially after the Cold War. ${ }^{1}$

\footnotetext{
${ }^{1}$ This conclusion is stated in 'Proposal for a programme of action for the elimination of nuclear weapons', submitted to the Conference on Disarmament by 28 members of the G-21 on 7 August 1996 (CD document CD/1419).
} 


\section{Preliminary Steps}

Prior to the initiation of substantive nuclear disarmament measures, certain preliminary steps are in order. The role of nuclear weapons in ensuring security should be delegitimized and existing nuclear doctrines abandoned - otherwise there will always be a threat of a resumption of the nuclear arms race and an escalation of the nuclear threat. Even though the Russian Federation and the United States are no longer locked in military confrontation and the prospect of nuclear warfare has receded, thousands of nuclear weapons are still on hair-trigger alert. The dangers inherent in high alert status are obvious. On land, ICBM's are ready to launch within minutes, and at sea, nuclear-armed submarines are on round-the-clock patrol. Other critical questions to be addressed in clued the risk of technical malfunction; ageing and obsolete weapons; early-warning system failures; inadvertent or accidental use of nuclear weapons; seizure of weapons or weapon materials and threats or actual use by non-state actors; and the dismantling of warheads, rather than just the delivery systems, such as missiles, which have been the focus of all previous nuclear arms control agreements.

Security issues are also of paramount importance to the vast majority of non-nuclear-weapon states. In April 1995, prior to the convening of the 1995 NPT Review and Extension Conference, individual declarations were made by the nuclear-weapon states on security assurances. They contain inherent weaknesses and deficiencies and leave ample room for subjective interpretations. There is also the danger that under certain circumstances, especially after the initiation of hostilities, such assurances may be unilaterally negotiated and they are unverifiable. They do not offer legitimate and binding assurances against the valid concerns of non-nuclear-weapon states. In the context of the imbalance of obligation between the nuclear-weapon states and the non-nuclearweapon states, which have renounced the right to acquire nuclear weapons, the latter called for unconditional and legally binding assurances in the form of an international convention. For without such iron-clad guarantees, the non-nuclear-weapon states would remain subject to the threat or use of nuclear weapons.

\section{Approaches to Nuclear Disarmament}

There have been no dearth of proposals for nuclear disarmament. This paper discusses the step-by-step approach which was considered by the UN General Assembly during the years 1993-95; the proposal of the Non-Aligned countries of a Programme of Action for the Elimination of Nuclear Weapons submitted in 1996; and the Report of the Canberra Commission which was also released during that year. 


\section{Step-by-Step Approach}

The following are general areas for a step-by-step reduction of the nuclear threat:

Area A - steps to prevent:

i. The acquisition and processing of special nuclear materials;

ii. The manufacture and testing of nuclear warheads and their delivery vehicles; and

iii. The assembly and deployment of nuclear-weapon systems.

These steps could be accomplished by actions such as cutting off the production of fissile materials for weapon purpose; ending production of nuclear warheads; ending the production and testing of intermediate and long-range ballistic missiles for weapons purpose; and other related measures.

Area B - steps to actuate:

i. The withdrawal from deployment and the disassembly of nuclearweapon systems;

ii. The secure storage and dismantlement for nuclear warheads and their delivery vehicles; and

iii. The elimination of special nuclear materials.

These steps could be accomplished by actions such as standing down nuclear-weapon systems from high-alert status; separating nuclear warheads from their delivery vehicles; removing nuclear weapons from their launch platforms; placing nuclear warheads in secure storage; converting delivery vehicle, where appropriate, to peaceful uses; placing plutonium stocks in international storage; dedicating special nuclear materials to non-weapon purpose; and other related measures.

Area $\mathrm{C}$ - steps to prepare:

i. An inventory of all nuclear arsenals including all special nuclear materials; nuclear warheads and their delivery vehicles; and all facilities devoted to the processing, manufacture, assembly, and deployment of those items;

ii. An inventory, and the adaption, of those facilities necessary to implement measure relating to Area B; and

iii. The closure or conversion to peaceful purpose of all other such facilities in furtherance of measures relating to Area A.

This step-by-step approach attempts to offer a mechanism that would allow the nuclear-weapon states to set out in an orderly and rational manner on the road to the gradual reduction of their nuclear stockpiles. This approach would envision an agreement on nuclear weapons limitation over a five to ten year period and would provide a muchneeded, overall direction to nuclear disarmament efforts.However, it falls short of the comprehensive approach to nuclear disarmament which 
is promoted by the UN General Assembly. It is widely perceived by the member states as a hindrance to quickening the pace of nuclear disarmament, because the steps agreed have often had little impact on the policies and capabilities of the nuclear-weapon states. For example, the Partial Test Ban Treaty did not halt nuclear testing which was continued underground. A step-by-step approach may give the illusion of progress, and reduce the impetus for significant steps. Consequently, the General Assembly during its $5^{\text {th }}$ session in 1995 decided to discontinue this approach, which it had adopted during the previous year, Instead it called for the elimination of nuclear armaments within a time-bound framework. Moreover, this step-by-step approach had been opposed by the nuclear-weapon state and a number of other countries.

Proposal for a Programme of Action for the Elimination of Nuclear Weapons submitted by the Non-Aligned countries comprised of three measures (Sur 1993).

First Phase - 1996-2000

A. Measure aimed at reducing the nuclear threat

- Immediate and concurrent commencement of negotiations and early conclusion of:

- a multilaterally negotiated legally binding instrument to assure non-nuclear weapon states against the use or threat of use of nuclear weapons;

- a convention prohibiting the use or threat of use of nuclear weapons;

- a treaty to eliminate nuclear weapons; and

- a treaty banning the production of fissile material for nuclear weapons.

- Ending the qualitative improvement of nuclear weapons, by agreements on:

- cessation of all nuclear weapon tests and closure of all nuclear weapon test sites; and

- measures to prevent the use of new technologies for the upgrading of existing nuclear weapons systems, including the prohibition of nuclear weapon research and development.

- Full implementation of the Treaties of Tlatelolco, Rarotonga, Pelindaba, and South-East Asia and establishment of additional nuclear-weapon-free zones, on the basis of arrangements freely arrived at among the states of the region concerned.

- Declarations of the stocks of nuclear weapons and of nuclearweapons-usable material.

B. Measures of nuclear disarmament

- Stand down nuclear-weapon systems from a state of operational readiness.

- Preservation of the ABM (And Ballistic Missile) Treaty. 
- Moratorium and prohibition on testing of outer space weapons systems.

- Ratification and implementation of the START II Treaty.

- Placement under IAEA safeguards of fissile material transferred from military to peaceful uses by the nuclear weapon states.

- Further negotiations for nuclear disarmament by all nuclearweapon states, including the cessation of production of nuclear warheads.

- Recommendation to the General Assembly to declare the decade 2000-2010 as the 'Decade for nuclear disarmament'.

Second Phase - 2000-2010

Measures to reduce the nuclear arsenals and to promote confidence between states.

- Entry into force of the treaty to eliminate nuclear weapons and establishment of a single integrated multilateral comprehensive verification system to ensure compliance, including measures such as:

- separation of nuclear warheads from their delivery vehicles;

- placement of nuclear warheads in secure storage under international supervision leading to the removal of special nuclear materials from warheads; and

- preparation under international auspices of an inventory of nuclear arsenals, including fissile materials, nuclear warheads and their delivery vehicles.

- Progressive and balanced reduction of missiles intended for carrying nuclear warheads.

- Recommendation to the General Assembly to declare the decade 2010-2010 as the 'Decade for the total elimination of nuclear weapons'.

Third Phase - 2010-2020

Consolidation of a nuclear-weapon-free world

- Adoption of principles and mechanisms for a global cooperative security system.

- Full implementation of the treaty to eliminate all nuclear weapons and of its verification regime through the completion of further measures such as :

- conversion of all facilities devoted to the production of nuclear weapons to peaceful purpose;

- application of safeguards on nuclear facilities on a universal basis; and

- elimination of all nuclear weapons. 


\section{The Report of the Canberra Commission on The Elimination of Nuclear Weapons}

The Report identified a series of steps which can be taken immediately to be followed by reinforcing steps. It also formulated a series of practical measures to bring about the elimination of nuclear weapons under appropriate verification mechanisms.

The immediate steps that were recommended includes

- Taking nuclear forces off alert;

- Removal of warheads from delivery vehicles;

- Ending deployment of non-strategic nuclear weapons;

- Initiating negotiations to further reduce the nuclear arsenals of the Russian Federation and The United States;

- Agreement among the nuclear-weapon states of reciprocal no-first use undertakings, and of a non-use undertaking by them in relation to the non-nuclear-weapon states.

The reinforcing steps includes

- Action to prevent further horizontal proliferation;

- Developing verification arrangements for a nuclear-weapon-free world;

- Cessation of the production of fissile material for nuclear weapons purpose.

The Canberra Commission also identified additional measures in the context of a possible verification regime. These were,

- Effective, cost-efficient non-proliferation controls over civil nuclear industry in all states;

- Mechanisms to detect undeclared nuclear activity;

- Ceasing production of fissile materials for nuclear weapons;

- The dismantlement and elimination of nuclear warheads;

- Placing warhead uranium and plutonium under IAEA safeguards;

- Controls over nuclear weapons components other than nuclear materials; and

- Dismantlement of nuclear weapons infrastructures.

\section{The Non-Proliferation Treaty}

Unlike other multilateral disarmament treaties, the NPT was not of indefinite duration. Many of the principal countries to which it was addressed (Germany, Italy, Japan and Switzerland) insisted on a short duration - a kind of trial period - as well as periodic review conferences, in order to ensure that the nuclear-weapon states would disarm before 
rendering permanent their own status as non-nuclear-weapon states. Thus, at the 1995 Review and Extension Conference the nuclear-weapon states won an astonishing victory by the decision taken to extend the Treaty indefinitely.The 1995 Conference witnessed the maintenance of the politics and positions of the nuclear-weapon states and their strategic posturing taking precedence over the fulfillment of their obligations. Issue long identified as critical components of the nonproliferation regime were marginalized in the decisions adopted by that Conference. Specifically, there was a lack of commitment to end the qualitative improvement of nuclear weapons; to launch the process of nuclear disarmament under multilateral auspices; and to assure the orderly flow of technology for the socioeconomic progress of the developing countries. The indefinite extension removed a sense of urgency from the obligations undertaken in Article VI of the Treaty and thereby perpetuated and legitimized the possession of nuclear weapons. The Conference also failed to adopt a final declaration thereby reflecting the fundamental differences between the nuclear-weapon states and non-nuclear-weapon states.

Yet the achievements of the Conference need to be recognized. The three decisions adopted: the indefinite extension of the Treaty; the Strengthening of the Review Process; and the Principles and Objectives for Non-Proliferation and Disarmament, which included the commitment to reduce nuclear weapons globally with the ultimate aim of their elimination and the indefinite extension, are inter-related and constitute a comprehensive package. Reflecting the view of the nonnuclear-weapon states, the President of the Conference stated that the indefinite extension was rendered possible on the basic of an understanding that meaningful and continuing progress would occur on nuclear disarmament.

In dealing with the question of non-proliferation, the cooperation of $\mathrm{s}$ number of key nations is indispensible. Such an approach allows for greater flexibility in accommodating the vital interests and widely differing circumstances of all nations. The issues confronting limitation of nuclear weapons is not only one of stemming proliferation but also of finding economic, strategic and security arrangements that apply equally to all states without discrimination. In short, a credible non-proliferation regime can only be sustained on the twin pillars of genuine disarmament measures and technical assistance for peaceful nuclear activities on an assured and predictable basis. 


\section{Nuclear-Weapon-Free Zones}

Article VII of the NPT has recognized the right of any group of states to conclude regional treaties to establish NWFZs. Such zones have now come to be generally recognized as making a significant contribution to the ultimate objective of achieving a world entirely free of nuclear weapons.The signature of the United State, the United Kingdom, and France to the Protocols of the Treaty of Rarotonga after ten years of efforts is among a number of recent positive developments. Significant steps have been taken to consolidate the Treaty of Tlatelolco. NWFZs have come into existence in the continent of Africa and in South-East Asia. The latter is the first such Treaty jointly conclude by all ten countries in the sub-region, but the nuclear-weapon states have yet to agree to its protocol, which reflect their long-held ambivalent position on NWFZs. A NWFZs is proposed for Central Asia. These developments reflects support for NWFZs as a means of promoting arms control, nonproliferation and nuclear disarmament and as an irreversible trend towards the establishment of such zones in regions where they do not exist.

\section{Cut-off the production of fissile material for nuclear weapons}

In September 1993, the US proposed a cut-off, that is, a ban in the production of plutonium or highly enriched uranium for nuclear weapons. Although the UN General Assembly endorsed the concept, reservations were expressed. First, there is not point in continuing to produce material that is already available in huge quantities. Hence, it does not entail any special constraints and enables the nuclear powers to propose a measure of nuclear disarmament that would have taken place in any case. Second, the ban would apply only to future production and no limits would be set on the use of previously produced materials.Yet a cut-off would strengthen, rather than weaken, disarmament efforts and ultimately reduce the danger posed by nuclear weapons. Based on formal agreements and informal understandings, the rollback of nuclear competition would be exemplified by sharp reductions in developed nuclear systems and mutually monitored dismantling of surplus warheads. A cut-off agreement would bolster this process by making legally binding the political decisions by the parties to stop producing material for weapons purpose (Dunn 194, 13-14). It would also constitute a symbolic step demonstrating that the nuclear arms race has leased and that 'good faith' negotiations are underway for nuclear disarmament, as called for in Article VI of the NPT. An agreement on cut-off poses a number of complex questions and problems including the following: Should the scope of an agreement be limited to future production only? Should stocks of materials be declared and limits be placed on their uses? Should continued production be permitted for non-weapons 
purpose? What should be the verification mechanism for a cut-off agreement? Will the IAEA be given a role in cut-off verification or should another verification mechanism be devised? (Dunn 194, 13-14). A cut-off should essentially be viewed as an interim arrangement, which should be part of a commitment to nuclear disarmament. It should also be stressed that a cut-off, like the CTBT and the NPT, by it self would do little more than preserve the nuclear status quo. If such agreements are to endure indefinitely, the nuclear powers must 'roll back' existing arsenals leading to their eventual elimination. Whether or not a cut-off is seen as a disarmament initiative on its own merits, or as part of a package, it is nonetheless part of an incremental process, reinforcing the trend of moving towards a nuclear-weapon-free culture. It does not guarantee a return to a non-nuclear world but may facilitate a trend away from a reliance on nuclear weapons. As long as a cut-off agreement is based upon universality and non-discrimination and does not deny civilian applications, it can be part of an incremental process of eliminating nuclear weapons.

\section{Reinforcing the bilateral agreement between the US and the Russian Federation}

Measure towards nuclear disarmament were beginning to be truly farreaching with the signing of INF, START I and START II Treaties, through which unprecedented steps were taken to slash both tactical and strategic nuclear forces. But these did not go far enough because, after reductions mandated by these Treaties, the two major powers will still deploy approximately the same number of strategic nuclear warheads that they did in 1970, the year when the NPT came into force. Despite an agreement between their leaders in 1994 and in 1997 to move to START II, no progress has been made. Proposals have been advanced by analysts and former officials for a reduction to the level series of unilateral actions and undertaken in a series of phased steps. Such warheads levels may persuade the lesser nuclear powers to join the process of eliminating nuclear weapons. This process should be irreversible, and include the dismantlement of weapons that are withdrawn and an undertaking not to modernize their arsenals.

\section{A build-down of nuclear arsenals}

Despite the significance of existing nuclear arms limitation agreements, they do not deal directly with the current stocks of nuclear warheads and missiles. To sustain their present levels indefinitely would be inviting disaster of an imaginable magnitude. Jonathan Dean has devised a safe and realistic programme for a genuine build-down of nuclear arsenals whose essential components are the following: (a) bilateral or multilateral monitoring of existing stocks of nuclear warheads and fissile 
material for weapons; (b) agreement to stop both the further production of warhead and fissile material for weapon purposes; (c) further drastic reduction in number of operationally deploy nuclear weapons; (d) obligatory dismantling of warheads reduced by negotiations, and the handing over of their fissile materials for bilaterally and multilaterally supervised storage; (e) obligatory destruction of missiles reduced by agreements; and (f) separating the remaining warheads from their delivery systems and monitoring both multilaterally to preclude any surprise attack. The implementation of these vario8s components into a unified approach would lead to a drastic reduction of nuclear arsenals and also eliminate the danger from the small remaining stock of nuclear weapons (Dean 1994, 98-99).

\section{Other approaches to Nuclear Disarmament}

In addition to the approaches to a nuclear-weapons-free world noted above, there are others that warrant consideration. Important among them is a commitment to a nuclear-weapon-free world by the nuclear powers. Such a commitment would greatly enhanced the prospects for international security, prepared the ground for more drastic cuts in nuclear armament and bolster efforts for the elimination of these weapons. A dramatic reduction of stockpiles and reappraisals of nuclear postures would instill a sense of security in the international community. Declaration of stockpiles of plutonium enriched uranium would enhance the overall transparency of nuclear weapon programmes and would constitute a valuable confidence building measure. It would also reinforce other in initiatives to remove suspicion and mistrust such as mutual visits to nuclear weapon facilities, discussion of nuclear doctrines and posture changes. Cooperative arrangement for managing nuclear weapons involving both nuclear and non nuclear states have become essentials. Such an approach would involve supervision of the final stage of nuclear disarmament, including custody of residual stocks of weapons and material and their eventual dismantling and destruction. International oversight is also essential for the dismantling of the entire weapons making complex (Dean 1994, 98-99). Reliable verification mechanisms are an essential prerequisite to ensure compliance with the agreement/treaties and to forestall any cheating. National technical means, transparency, international monitoring and cooperative measure are among the many approaches to verification. There is a wealth of experience to be gained from the IAEA, INF, CFE, START I and II as well as verification capabilities of OPCW. The demand for the verification regime to ensure the elimination of all nuclear weapons is unrealistic and can only be regarded as having questionable political overtones. 


\section{Conclusion}

Why are nuclear-weapon states opposed to initiating a process of genuine nuclear disarmament? It is partly due to the inertia of old habits developed over decades. It is also due to the fear of losing a status which they would deny to others. The real issue is whether we are ready to accept nuclear weapons as a permanent feature of our world or continue to regard their existence as a transitory phase in contemporary history? The situation regarding the non-proliferation of nuclear weapons is complicated. The technology for their manufacture has become more accessible and what was once a monopoly of a few is now available to many. What is invented today to enhance one's security has a tendency to reappear elsewhere as a threat. It seems to offer security until it is developed by others. The cycle then repeats. Notwithstanding the NPT, a number of countries possess the technology, the fissile materials and financial resources to 'go nuclear' in a matter of months. The nuclearweapon states must set an example and pave the way towards nuclear disarmament. They should put forward a comprehensive nuclear disarmament programme. They should begin by committing themselves to the total abolition of nuclear weapons in accordance with a phased programme. Then they should identify concrete steps to reduce the nuclear threat. Finally, they should identify those nuclear disarmament measures which they could take unilaterally, bilaterally with other nuclear weapon states, and multilaterally within a given period or periods. This would have the most beneficial effects on the way the nonnuclear-weapon states view their relationship between nuclear-weapon states and their nuclear arsenals.

One school of thought, mostly in the Western nuclear-weapon states, argues that nuclear disarmament is a very complicated matter and that nuclear-weapon states cannot pursue it in phases. But the nuclear arms race and buildup did not follow a predetermined pattern: it often responded to specific goals that had to be met by specific dates. The efforts to build the first bomb and later to move from atomic to hydrogen bombs are example. The same is true for the development of delivery vehicles, in particular, the evolution of missile technology. If countries developed their nuclear arsenals by earmarking resources for specific projects to be completed by a set date, it is possible to do the same when they build down and dismantle their nuclear weapons.

In the past, nuclear-weapon states have been either reluctant to examine substantive questions at Review Conference, and avoided any debate on these questions, or refused to do so. Their actions call for a review of whether the policies of nuclear-weapon states conform with their NPT obligations. The international community has a right to expect that the 
nuclear-weapon states will be more forthcoming within the preparatory process of the 2000 NPT Review Conference.

Nuclear weapons remain extremely dangerous: their indefinite retention brings risks of further proliferation and, sooner or later, of use, either by design or by accident. In an insecure and dangerous world, nuclear disarmament has become even more indispensable. In the post-Cold War era, there is a window of opportunity to make nuclear-weapons reductions irreversible and move towards their internationally verifiable abolition. If we miss the present opportunity and continue with an outmoded way of thinking, a new period of global tension may result, together with a renewed nuclear arms race aggravated by new technological developments and by further proliferation. It is therefore time to initiate negotiations for nuclear disarmament in all its aspects under multilateral auspices leading to the conclusion of a Nuclear Weapons Convention.

\section{References}

\section{Books}

Baker III, James A. and De Frank, Thomas N., 1995. The Politics of Diplomacy : Revolution, War and Peace 1989-1992, G.P. Putnam's Sons.

Sur, Serge (ed.) Nuclear Deterrence: Problems and Perspectives in the 1990's, UNIDIR, Geneva, 1993.

\section{Journal Article}

Dean, Jonathan. 1994. Dean The Final Stage of Nuclear Arms Control: How to achieve it? Disarmament: A Periodic Review by the United Nations, Vol. XVII, No. 2, 1994, pp.98-99.

\section{Research Paper}

Dunn, Lewis,1994. A Nuclear-Weapons Materials Cut-off : An Idea whose time has come in halting the Production of Fissile Materials for Nuclear Weapons, Research Paper, No. 31, UNIDIR, Geneva, 1994, pp.13-14.

\section{Periodicals}

Christian Science Monitor, Boston, 5 December 1996 


\section{Government Publication}

Department of Foreign Affairs and Trade. 1996.Canberra, theGovernment of Australia.

\section{Others}

Butler, Richard. 1996. Public Lecture on "The Elimination of Nuclear Weapon's".Delivered on 1 May 1996 at the University of New England, Australia.

'Proposal for a programme of action for the elimination of nuclear weapons', submitted to the Conference on Disarmament by 28 members of the G-21 on 7 August 1996 (CD document CD/1419). 